\title{
Synergistic effect of exogenous multi-enzyme and phytase on growth performance, nutrients digestibility, blood metabolites, intestinal microflora and morphology in broilers fed corn-wheat-soybean meal diets
}

\author{
MinJu Kim ${ }^{1}$, Santosh Laxman Ingale ${ }^{2}$, Abdolreza Hosseindoust ${ }^{3}$, YoHan Choi $^{4}$, \\ KwangYeol Kim ${ }^{3}$, and ByungJo Chae ${ }^{3, *}$
}

\author{
* Corresponding Author: ByungJo Chae \\ Tel: +82-33-250-8616, Fax: +82-33-244-4946, \\ E-mail: bjchae@kangwon.ac.kr \\ ${ }^{1}$ Centre for Nutrition and Food Sciences, \\ Queensland Alliance for Agriculture \\ and Food Innovation, The University of \\ Queensland, QLD 4072, Australia \\ ${ }^{2}$ Advanced Enzyme Technologies Ltd., Thane \\ 400604, India \\ ${ }^{3}$ College of Animal Life Sciences, Kangwon \\ National University, Chuncheon 24341. \\ Korea \\ ${ }^{4}$ Swine Division, National Institute of Animal \\ Science, Rural Development Administration, \\ Cheonan 31000, Korea \\ ORCID \\ MinJu Kim \\ https://orcid.org/0000-0001-6950-0458 \\ Santosh Laxman Ingale \\ https://orcid.org/0000-0001-6963-3947 \\ Abdolreza Hosseindoust \\ https://orcid.org/0000-0001-9191-0613 \\ YoHan Choi \\ https://orcid.org/0000-0003-4710-4731 \\ KwangYeol Kim \\ https://orcid.org/0000-0002-3723-2978 \\ ByungJo Chae \\ https://orcid.org/0000-0002-8570-698X
}

Submitted Sept 20, 2020; Revised Oct 19, 2020; Accepted Dec 12, 2020
Objective: This study was conducted to investigate the synergistic effect of exogenous multienzyme and phytase on growth performance, nutrients digestibility, blood metabolites, intestinal microflora, and morphology in broilers fed corn-wheat-soybean meal diets.

Methods: A $2 \times 2$ factorial design was used in this study. Four dietary treatments consisted of i) basal diets (corn-wheat-soybean meal based diets without multi-enzyme and phytase), ii) basal diets with phytase $(0.05 \%)$, iii) basal diets with exogenous multi-enzyme $(0.05 \%)$, and iv) basal diets with exogenous multi-enzyme including phytase (0.05\%). A total of 480 broiler chickens (Ross 308 - one day old) were weighed and allotted to thirty-two cages (15 birds per cage), and chicks were randomly allocated to four dietary treatments.

Results: The body weight gain and feed conversion rate were improved by supplementation of exogenous multi-enzyme containing phytase during the finisher period $(p<0.05)$. The birds fed diets with exogenous multi-enzyme containing phytase had a significantly greater digestibility of dry matter, gross energy, crude protein, calcium, and phosphorus compared with birds fed non-supplemented diets $(\mathrm{p}<0.05)$. The chickens fed diets with exogenous multi-enzyme containing phytase showed a higher concentration of $\mathrm{Ca}$ and $\mathrm{P}$ in the serum ( $<<0.05$ ). The population of Lactobacillus spp., Escherichia coli, and Clostridium were not affected in the ileum and cecum of chickens fed enzyme-supplemented diets. The dietary supplemental exogenous multi-enzyme containing phytase showed a significant improvement in villus height, crypt depth, and villus height and crypt depth ratio, compared to basal diets or dietary supplemental phytase $(\mathrm{p}<0.05)$.

Conclusion: The supplementation of the exogenous multi-enzyme containing phytase synergistically improved the growth performance, nutrients digestibility, and villus height of the small intestine of broiler chickens fed a corn-wheat-soybean meal based diets.

Keywords: Exogenous Enzyme; Broiler Chickens; Phytase; Nutrients Digestibility; Gut Microflora; Growth Performance

\section{INTRODUCTION}

The poultry diets are mainly comprised of the grains such as corn, wheat, and soybean meal (SBM) that contain non-starch polysaccharides (NSP) (10\% to $22.7 \%)$ as anti-nutritional factors, which have physiological impacts in chickens. NSP in corn, SBM, and wheat are mainly insoluble types, as arabinoxylan and $\beta$-galactomannan in corn and $\alpha$-galactosides and $\beta$-galacto-mannan in SBM, and arabinoxylan in wheat [1-4]. Insoluble NSP encapsulating nutrients inside the cell wall make them unavailable for digestion, increasing the 
digesta viscosity and $\mathrm{pH}$, and disturbing the action of endogenous enzymes in the gut [5-8]. Feedstuff such as corn, SBM, and wheat have phytate that retain carbohydrates, microminerals, amino acids, and some digestive enzymes, which in turn impedes the absorption of nutrients in broiler diets as endogenous phytase is not produced in the gut of chickens [9].

Supplemental exogenous enzymes in broiler diets have been used to release the chemical structure of NSP and to improve the growth performance and nutrient digestibility [10-12]. Amerah et al [13] reported that increased weight gain and feed conversion ratio (FCR) was shown in boilers when a corn-SBM based diet was supplemented with exogenous multi-enzymes compared to single enzyme supplementation by decreasing ileal flow of components of soluble and insoluble non-starch polysaccharides. Furthermore, supplementation of xylanase in wheat-SBM based diet decreased ileal digesta viscosity and improved growth performance and apparent ileal digestibility of nutrients in broilers $[14,15]$. However, Wu et al [16] observed that supplementation of exogenous enzymes such as xylanase and phytase individually in wheatbased diet improved the growth performance and reduced the small intestinal viscosity, while the combination of phytase and xylanase caused no further improvements on broiler performance.

It is speculated that if dietary exogenous multi-enzyme and phytase are supplemented in combination in the diets, a synergistic effect would be shown in broiler chickens. This study was conducted to investigate the effect of exogenous multi-enzyme including phytase on growth performance, nutrients digestibility, blood metabolites, gut microbiota, and small intestinal morphology in broilers fed corn-wheatSBM diets.

\section{MATERIALS AND METHODS}

The experiment was conducted at the facility of Kangwon National University farm and all animal experimental procedures and protocol in this research were approved by the Institutional Animal Care and Use Committee of Kangwon National University, Republic of Korea (Approval No: KW141111-1).

\section{Animals, diets, and experimental design}

A randomized complete block design consisting of a $2 \times 2$ factorial design was used in this study. The enzymes used in this experiment were supplied by Advanced Enzyme Technologies Ltd. (Thane, India). Exogenous multi-enzymes used in this study were two types, enzyme blend as amylase, protease, mannanase, and xylanase and enzyme blend including phytase. The treatments included: i) basal diets (corn-wheatSBM based diets without enzyme), ii) basal diets with phytase
(DigePhos 5G, Advanced Enzyme Technologies, India) $(0.05 \%)$, iii) basal diets with exogenous multi-enzyme (DigeGrain Delta, Advanced Enzyme Technologies, India) (0.05\%), and iv) basal diets with exogenous multi-enzyme including phytase $(0.05 \%)$. A total of 480 one-day old Ross 308 chicks ( $47.74 \pm 0.8 \mathrm{~g}$, body weight $[\mathrm{BW}]$ ) were randomly allotted to 8 replicates of 15 birds per treatment. This experiment was conducted for a total of 35 days (phase $1, \mathrm{~d} 0$ to 21 and phase $2, \mathrm{~d} 22$ to 35). The nutrient contents of experimental diets (Table 1) were formulated in order to meet or exceed nutrient requirements by Nutrient Requirements of Poultry [17]. The birds were raised in floor pens with rice husks used as beddings (about $5 \mathrm{~cm}$ in depth). Each pen was equipped with a hopper feeder and five water nipple drinkers connected

Table 1. Formula and chemical composition of experimental diets (as-fed basis)

\begin{tabular}{|c|c|c|}
\hline Items & $\begin{array}{c}\text { Starter } \\
\text { (d 0-21) }\end{array}$ & $\begin{array}{l}\text { Finisher } \\
\text { (d 21-35) }\end{array}$ \\
\hline \multicolumn{3}{|l|}{ Ingredient (\%) } \\
\hline Corn & 53.47 & 50.92 \\
\hline Wheat & 5.00 & 10.00 \\
\hline Soybean meal (45\%) & 27.98 & 23.10 \\
\hline Fish meal (60\%) & 2.00 & - \\
\hline Corn gluten & 4.36 & 7.00 \\
\hline Soy-oil & 2.77 & 4.47 \\
\hline Threonine (98.5\%) & 0.07 & 0.07 \\
\hline Lysine (78\%) & 0.17 & 0.25 \\
\hline Methionine (50\%) & 0.56 & 0.43 \\
\hline Tryptophan (10\%) & - & 0.02 \\
\hline Choline & 0.05 & 0.05 \\
\hline Limestone & 1.76 & 1.75 \\
\hline MDCP & 1.11 & 1.24 \\
\hline Salt & 0.20 & 0.20 \\
\hline Mineral premix ${ }^{1)}$ & 0.20 & 0.20 \\
\hline Vitamin premix ${ }^{2)}$ & 0.30 & 0.30 \\
\hline Total & 100.00 & 100.00 \\
\hline \multicolumn{3}{|l|}{ Nutrient composition (\%) } \\
\hline Metabolic energy (Kcal/kg) & 3,050 & 3,150 \\
\hline Crude protein & 22.00 & 20.00 \\
\hline Crude protein (analyzed) & 22.13 & 20.08 \\
\hline Crude fiber (analyzed) & 2.62 & 2.51 \\
\hline Crude ash (analyzed) & 2.65 & 2.44 \\
\hline Ether extract (analyzed) & 4.72 & 4.50 \\
\hline Calcium & 1.00 & 0.90 \\
\hline Available phosphorus & 0.40 & 0.38 \\
\hline Lysine & 1.20 & 1.07 \\
\hline TSAA & 0.94 & 0.80 \\
\hline Threonine & 0.80 & 0.70 \\
\hline Tryptophan & 0.22 & 0.19 \\
\hline
\end{tabular}

MDCP, mono-dicalcium phosphate; TSAA, total sulfur amino acids.

1) Supplied per kg diet: 20 mg Fe, 16 mg Cu, 110 mg Zn, 120 mg Mn, 1.25 mg l, 0.9 mg Co, 0.3 mg Se.

2) Supplied per kg diet: 10,000 IU vitamin $A, 4,500$ IU vitamin $D_{3}, 65 \mathrm{mg}$ vitamin $E, 1.5 \mathrm{mg}$ vitamin $\mathrm{B}_{1}, 12 \mathrm{mg}$ vitamin $\mathrm{B}_{2}, 3.2 \mathrm{mg}$ vitamin $\mathrm{B}_{6}, 0.011$ $\mathrm{mg}$ vitamin $\mathrm{B}_{12}, 3.0 \mathrm{mg}$ vitamin $\mathrm{K}_{3}, 18 \mathrm{mg}$ pantothenic acid, $60 \mathrm{mg}$ niacin, $0.18 \mathrm{mg}$ biotin, $1.9 \mathrm{mg}$ folic acid, $18 \mathrm{mg}$ ethoxyquin. 
to water tank, allowing the birds to take feed and water " $a d$ libitum". The chicks were kept at a temperature of $34^{\circ} \mathrm{C}$ for $\mathrm{d}$ 1 to 3 , and thereafter the temperature was gradually decreased to $23^{\circ} \mathrm{C}$ according to normal management practices. All birds were under a continuous lighting for $23 \mathrm{~h} / \mathrm{d}$.

\section{Experimental procedure and sampling}

The BW and feed intake (FI) of chickens per pen were measured at the start and end of each phase for calculation of the body weight gain (BWG) and FCR. To determine the apparent total tract digestibility (ATTD), chromic oxide (Cr, $0.25 \%$ ) was added in each diet as a marker. Two birds from each pen were allocated in individual cages and fed experimental diets for 10 days, $5 \mathrm{~d}$ for adaptive period and $5 \mathrm{~d}$ for sampling period. The excreta samples from each pen were pooled into stainless trays to analyze ATTD of dry matter (DM), gross energy (GE), crude protein (CP), calcium (Ca), and phosphorus $(\mathrm{P})$. The pooled excreta samples per treatment were dried in a forced-air oven at $60^{\circ} \mathrm{C}$ for $72 \mathrm{~h}$. Thereafter, the dried samples were ground by an electric feed grinder (Thomas Model 4 Wiley Mill, Thomas Scientific, Swedesboro, NJ, USA) and sieved through a 1-mm screen for chemical analysis.

Two birds per pen were randomly chosen for blood collection. Blood samples were taken from the wing vein with disposable vacutainers containing heparin sodium at $\mathrm{d} 21$ and d 35 and centrifuged at $3,000 \mathrm{rpm}$ for $15 \mathrm{~min}$ at $4^{\circ} \mathrm{C}$. Then, the supernatant of samples was moved to $1 \mathrm{~mL}$ tube by pipette and stored at $-20^{\circ} \mathrm{C}$ before analysis of blood metabolites. Three birds per replicate were slaughtered at $\mathrm{d} 35$ to collect samples for analysis of the apparent ileal digestibility (AID) of nutrients, gut microflora in ileum and cecum, and small intestinal morphology. The ileum and cecum contents were stored in sterilized plastic bottles at $7^{\circ} \mathrm{C}$ and transferred to laboratory immediately for bacterial analysis. The intestinal samples (approximately $3 \mathrm{~cm}$ in length) were acquired from the duodenum (middle portion of the duodenal loop), jejunum (midway between the distal portion of the duodenal loop and Meckel's diverticulum), and ileum (midway between Meckel's diverticulum and ileo-cecal junction). The intestinal contents were washed with phosphate-buffered saline and the samples were fixed by buffered formalin (10\%) for analysis of the intestinal morphology.

\section{Chemical and microbial analysis}

Experimental diets and excreta samples were analyzed according to methods described by AOAC [18] in triplicate for DM (930.15), CP (990.03), and ash (942.05) Ca, and P (985.01). The GE was assessed by using a bomb calorimeter (Model 1261, Parr Instrument Co., Moline, IL, USA), and chromium (Cr) concentration was measured with an automated spectrophotometer (Jasco V-650, Jasco Corp., Tokyo, Japan) according to the procedure of Fenton and Fenton [19]. Analysis of serum metabolites was conducted by using an automated chemistry analyzer (Fuji Dri-chem 3500i; Fujifilm Corp., Tokyo, Japan).

The microbiological assay was carried out by the procedure suggested by Kim et al [20]. The excreta samples from ileum and cecum per replicate were pooled in a sterilized plastic bottles and mixed. The samples $(1 \mathrm{~g})$ were put together in anaerobic dilution solution $(9 \mathrm{~mL})$ by keeping it under $\mathrm{CO}_{2}$. The serial dilutions $\left(10^{-5}\right.$ to $\left.10^{-8}\right)$ were made by using the anaerobic dilution solution, and $1 \mathrm{~mL}$ diluted solution was plated onto agar plates in triplicate. The total anaerobic bacteria were determined on plate count agar (TAB, Difco Laboratories, Detroit, MI, USA) and incubated at $37^{\circ} \mathrm{C}$ for $24 \mathrm{~h}$ under anaerobic condition. The Lactobacillus spp. was determined on MRS agar (with $0.20 \mathrm{~g} / \mathrm{L} \mathrm{NaN}_{3}+0.50 \mathrm{~g} / \mathrm{L} \mathrm{L}$ cystine hydrochloride monohydrate) and incubated at $39^{\circ} \mathrm{C}$ for $48 \mathrm{~h}$ under aerobic conditions. The Clostridium spp. was determined on tryptose sulphite cycloserine agar (Oxoid, Hampshire, UK) and incubated at $37^{\circ} \mathrm{C}$ for $24 \mathrm{~h}$ under anaerobic conditions. The Escherichia coli (E. coli) was determined on MacConkey agar and incubated at $37^{\circ} \mathrm{C}$ for $24 \mathrm{~h}$ under aerobic conditions. The anaerobic condition was made in a gas-pack anaerobic system (BBL, No. 260678, Difco, USA).

\section{Small intestinal morphology}

The samples of duodenum, jejunum and ileum were processed with ethanol for one day and were embedded in standard paraffin. Intestinal samples were stained with azure A and eosin and then well-oriented crypt-villus groups (total 10 intact) were selected for intestinal cross-sections. The samples were measured in triplicates by using an optical microscope and image analysis system (Media Cyber genetics, Optimus software version 6.5, North Reading, MA, USA). Villus height $(\mathrm{VH}, \mu \mathrm{m})$ was determined from the top of the villus to crypts of Lieberkühn and crypt depth $(\mathrm{CD}, \mu \mathrm{m})$ was measured as the depth of the invagination between ad-jacent villi. All morphological characteristics were analyzed in $10-\mu \mathrm{m}$ increments.

\section{Statistical analyses}

All data was analyzed by general linear model procedure of SAS (SAS Inst. Inc., Cary, NC, USA) as $2 \times 2$ factorial arrangement with dietary treatments of exogenous multi-enzyme and phytase as main effects. Significant differences among the treatment means were partitioned by Tukey's honestly significant difference test at $\mathrm{p}<0.05$ statistical level, and $0.05<$ $\mathrm{p}<0.10$ was considered a trend towards significance. Pens were considered the experimental unit for growth performance and broiler chickens were considered the experimental unit for measuring the nutrients digestibility, blood metabolites, gut microbiota, and intestinal morphology. 


\section{RESULTS}

\section{Growth performance}

The results of growth performance are presented in Table 2. The broilers fed diet supplemented with multi-enzyme and phytase improved significantly in the BWG and FCR at starter and finisher phases $(\mathrm{p}<0.05)$. Furthermore, the supplementation of multi-enzyme and phytase in combination had an interaction effect in BWG during finisher phase $(\mathrm{p}<0.05)$. The broilers fed diet supplemented with multi-enzyme with phytase had significantly better FCR than broilers fed diet supplemented with multi-enzyme or phytase individually $(\mathrm{p}<0.05)$.

\section{Digestibility of nutrients}

The results of nutrients digestibility in feces and ileum are shown in Table 3. The exogenous multi-enzyme significantly improved the ATTD and AID of DM, GE, and CP $(p<0.05)$ and phytase enhanced the digestibility of $\mathrm{Ca}$ and $\mathrm{P}$ in both ATTD and AID $(\mathrm{p}<0.05)$. No interaction between exogenous multi-enzyme and phytase was observed. The exogenous multi-enzyme containing phytase supplementation showed the significant increases of ATTD and AID in DM, GE, CP, $\mathrm{Ca}$, and $\mathrm{P}$ compared to basal diets, supplemental phytase without multi-enzyme, or supplemental multi-enzyme without phytase treatment $(\mathrm{p}<0.05)$.

Table 2. Effects of dietary supplementation of exogenous multi-enzyme containing phytase on growth performance in broilers

\begin{tabular}{|c|c|c|c|c|c|c|c|c|}
\hline \multirow{2}{*}{ Items } & \multicolumn{2}{|c|}{-Enzyme } & \multicolumn{2}{|l|}{+ Enzyme $^{1)}$} & \multirow{2}{*}{ SEM } & \multicolumn{3}{|c|}{ p-value } \\
\hline & -Phytase & +Phytase & -Phytase & +Phytase & & $\mathbf{E}$ & $\mathbf{P}$ & ExP \\
\hline \multicolumn{9}{|c|}{ Starter (d 0 to 21 ) } \\
\hline BWG (g) & $774^{b}$ & $807^{a}$ & $812^{a}$ & $827^{a}$ & 7.16 & $<0.001$ & 0.003 & 0.241 \\
\hline $\mathrm{FI}(\mathrm{g})$ & 1,176 & 1,186 & 1,185 & 1,190 & 11.68 & 0.603 & 0.526 & 0.817 \\
\hline FCR & $1.52^{\mathrm{a}}$ & $1.47^{\mathrm{ab}}$ & $1.46^{\mathrm{b}}$ & $1.44^{\mathrm{b}}$ & 0.02 & 0.016 & 0.063 & 0.454 \\
\hline \multicolumn{9}{|c|}{ Finisher (d 21 to 35) } \\
\hline BWG (g) & $1,096^{\mathrm{C}}$ & $1,136^{b}$ & $1,143^{b}$ & $1,160^{\mathrm{a}}$ & 3.47 & $<0.001$ & $<0.001$ & 0.003 \\
\hline $\mathrm{FI}(\mathrm{g})$ & 2,067 & 2,113 & 2,103 & 2,054 & 19.78 & 0.589 & 0.942 & 0.029 \\
\hline FCR & $1.89^{\mathrm{a}}$ & $1.86^{\mathrm{a}}$ & $1.84^{\mathrm{a}}$ & $1.77^{b}$ & 0.02 & 0.001 & 0.012 & 0.234 \\
\hline \multicolumn{9}{|c|}{ Overall (d 0 to 35) } \\
\hline BWG (g) & $1,867^{\circ}$ & $1,943^{b}$ & $1,955^{b}$ & $1,988^{\mathrm{a}}$ & 7.98 & $<0.001$ & $<0.001$ & 0.018 \\
\hline $\mathrm{FI}(\mathrm{g})$ & 3,243 & 3,299 & 3,288 & 3,244 & 23.60 & 0.832 & 0.803 & 0.044 \\
\hline FCR & $1.74^{\mathrm{a}}$ & $1.70^{\mathrm{b}}$ & $1.68^{b}$ & $1.63^{c}$ & 0.01 & $<0.001$ & 0.001 & 0.724 \\
\hline
\end{tabular}

E, multienzyme; P, phytase; SEM, standard error of means; BWG, body weight gain; Fl, feed intake; FCR, feed conversion ratio.

1) Enzyme, multi-exogenous enzyme contained with amylase, protease, mannanase, and xylanase.

${ }^{a-c}$ Means within a row with unlike superscripts differ significantly $(p<0.05)$.

Table 3. Effects of dietary supplementation of exogenous multi-enzyme containing phytase on ATTD and AID (\%) in broilers

\begin{tabular}{|c|c|c|c|c|c|c|c|c|}
\hline \multirow{2}{*}{ Items } & \multicolumn{2}{|c|}{-Enzyme } & \multicolumn{2}{|c|}{ +Enzyme ${ }^{1)}$} & \multirow{2}{*}{ SEM } & \multicolumn{3}{|c|}{ p-value } \\
\hline & -Phytase & +Phytase & -Phytase & +Phytase & & $E$ & $\mathbf{P}$ & ExP \\
\hline \multicolumn{9}{|l|}{ ATTD } \\
\hline DM & $74.05^{b}$ & $74.52^{b}$ & $74.86^{\mathrm{ab}}$ & $75.55^{a}$ & 0.33 & 0.011 & 0.097 & 0.733 \\
\hline GE & $75.05^{b}$ & $75.67^{\mathrm{ab}}$ & $75.88^{\mathrm{ab}}$ & $76.52^{a}$ & 0.29 & 0.016 & 0.064 & 0.954 \\
\hline $\mathrm{CP}$ & $66.51^{c}$ & $66.92^{\mathrm{bc}}$ & $68.20^{\mathrm{ab}}$ & $68.62^{a}$ & 0.54 & 0.004 & 0.457 & 0.995 \\
\hline $\mathrm{Ca}$ & $40.03^{b}$ & $41.84^{a b}$ & $40.71^{\mathrm{ab}}$ & $42.31^{a}$ & 0.64 & 0.380 & 0.014 & 0.875 \\
\hline$P$ & $38.39^{c}$ & $40.38^{\mathrm{ab}}$ & $39.26^{a b c}$ & $41.03^{\mathrm{a}}$ & 0.66 & 0.265 & 0.009 & 0.865 \\
\hline \multicolumn{9}{|l|}{ AID } \\
\hline DM & $75.47^{b}$ & $76.03^{a b}$ & $76.29^{\mathrm{ab}}$ & $77.02^{a}$ & 0.34 & 0.018 & 0.083 & 0.812 \\
\hline GE & $76.52^{b}$ & $77.09^{b}$ & $77.41^{\mathrm{ab}}$ & $78.35^{\mathrm{a}}$ & 0.37 & 0.015 & 0.079 & 0.660 \\
\hline $\mathrm{CP}$ & $67.93^{b}$ & $68.35^{b}$ & $69.46^{\mathrm{ab}}$ & $70.09^{a}$ & 0.54 & 0.006 & 0.343 & 0.849 \\
\hline $\mathrm{Ca}$ & $41.30^{\mathrm{b}}$ & $43.02^{a b}$ & $41.90^{\mathrm{ab}}$ & $43.78^{\mathrm{a}}$ & 0.67 & 0.330 & 0.013 & 0.908 \\
\hline$P$ & $39.98^{b}$ & $41.85^{\mathrm{ab}}$ & $40.67^{\mathrm{ab}}$ & $42.69^{a}$ & 0.68 & 0.271 & 0.008 & 0.913 \\
\hline
\end{tabular}

E, multienzyme; P, phytase; SEM, standard error of means; ATTD, apparent total tract digestibility; AID, apparent ileal digestibility; DM, dry matter; GE, gross energy; CP, crude protein; Ca, calcium; P, phosphorus.

1) Enzyme, multi-exogenous enzyme contained with amylase, protease, mannanase, and xylanase.

${ }^{a-c}$ Means within a row with unlike superscripts differ significantly $(p<0.05)$. 


\section{Blood metabolites}

The results of blood metabolites are shown in Table 4 . There was no interaction between exogenous multi-enzyme and phytase. The concentration of $\mathrm{Ca}$ and $\mathrm{P}$ in serum was significantly increased with phytase supplementation on $\mathrm{d} 21$ and $\mathrm{d} 35(\mathrm{p}<0.05)$. The treatment supplemented with exogenous multi-enzyme containing phytase had the highest concentration of $\mathrm{Ca}$ and $\mathrm{P}$ in serum amongst the four treatment groups $(\mathrm{p}<0.05)$.

\section{Ileum and cecum microflora}

The results of intestinal microflora are shown in Table 5. No significant effects on multi-enzyme, phytase and their inter- action were observed $(\mathrm{p}>0.05)$. There were no difference in population of Lactobacillus spp., E. coli, and Clostridium spp. in the ileum and cecum of chicken fed diet supplemented with exogenous multi-enzyme.

\section{Small intestinal morphology}

The results of intestinal morphology are presented in Table 6. The exogenous multi-enzyme with phytase significantly increased the $\mathrm{VH}$ and decreased the $\mathrm{CD}$ in all intestinal segments $(\mathrm{p}<0.05)$. However, no interaction in supplementation of exogenous multi-enzyme and phytase was observed. The exogenous multi-enzyme containing phytase showed the most significant increase of $\mathrm{VH}$, decrease of $\mathrm{CD}$, and im-

Table 4. Effects of dietary supplementation of exogenous multi-enzyme containing phytase on blood metabolites in broilers

\begin{tabular}{|c|c|c|c|c|c|c|c|c|}
\hline \multirow{2}{*}{ Items } & \multicolumn{2}{|c|}{-Enzyme } & \multicolumn{2}{|c|}{ +Enzyme ${ }^{1)}$} & \multirow{2}{*}{ SEM } & \multicolumn{3}{|c|}{ p-value } \\
\hline & -Phytase & +Phytase & -Phytase & +Phytase & & $E$ & $\mathbf{P}$ & ExP \\
\hline \multicolumn{9}{|c|}{ Glucose (mg/dL) } \\
\hline $35 d$ & 254.38 & 240.00 & 251.50 & 237.75 & 6.29 & 0.687 & 0.034 & 0.961 \\
\hline \multicolumn{9}{|c|}{ Triglyceride (mg/dL) } \\
\hline $21 d$ & 31.25 & 28.25 & 24.63 & 28.38 & 2.10 & 0.144 & 0.863 & 0.129 \\
\hline $21 d$ & 130.13 & 128.25 & 125.25 & 125.50 & 2.31 & 0.112 & 0.729 & 0.651 \\
\hline $35 d$ & 122.00 & 126.38 & 121.13 & 124.00 & 2.09 & 0.446 & 0.095 & 0.724 \\
\hline \multicolumn{9}{|c|}{$\mathrm{Ca}(\mathrm{mg} / \mathrm{dL})$} \\
\hline $21 d$ & $10.19^{b}$ & $10.54^{\mathrm{ab}}$ & $10.35^{\mathrm{ab}}$ & $10.68^{a}$ & 0.12 & 0.254 & 0.014 & 0.923 \\
\hline $35 d$ & $10.26^{b}$ & $10.68^{\mathrm{ab}}$ & $10.45^{\mathrm{ab}}$ & $10.85^{\mathrm{a}}$ & 0.16 & 0.279 & 0.020 & 0.970 \\
\hline
\end{tabular}

SEM, standard error of means; E, multienzyme; P, phytase; Ca, calcium; P, phosphorus.

1) Enzyme, multi-exogenous enzyme contained with amylase, protease, mannanase, and xylanase.

$a, b$ Means within a row with unlike superscripts differ significantly $(p<0.05)$.

Table 5. Effects of dietary supplementation of exogenous multi-enzyme containing phytase on ileum and cecum microflora in broilers

\begin{tabular}{|c|c|c|c|c|c|c|c|c|}
\hline \multirow{2}{*}{ Items } & \multicolumn{2}{|c|}{-Enzyme } & \multicolumn{2}{|c|}{ +Enzyme ${ }^{1)}$} & \multirow{2}{*}{ SEM } & \multicolumn{3}{|c|}{$p$-value } \\
\hline & -Phytase & +Phytase & -Phytase & +Phytase & & $E$ & $\mathbf{P}$ & ExP \\
\hline \multicolumn{9}{|c|}{ Total anaerobic bacteria } \\
\hline Cecum & 10.11 & 9.95 & 9.96 & 9.96 & 0.06 & 0.219 & 0.204 & 0.197 \\
\hline \multicolumn{9}{|c|}{ Lactobacillus spp. } \\
\hline Ileum & 8.89 & 9.25 & 9.27 & 9.31 & 0.12 & 0.073 & 0.101 & 0.195 \\
\hline Ileum & 7.53 & 7.28 & 7.26 & 7.23 & 0.08 & 0.081 & 0.111 & 0.211 \\
\hline Cecum & 7.66 & 7.40 & 7.37 & 7.33 & 0.09 & 0.069 & 0.129 & 0.255 \\
\hline \multicolumn{9}{|c|}{ Clostridium spp. } \\
\hline Ileum & 7.36 & 7.04 & 7.08 & 7.03 & 0.10 & 0.175 & 0.092 & 0.197 \\
\hline Cecum & 7.58 & 7.30 & 7.23 & 7.25 & 0.11 & 0.081 & 0.261 & 0.191 \\
\hline
\end{tabular}

SEM, standard error of means; E, multienzyme; P, phytase.

${ }^{1)}$ Enzyme, multi-exogenous enzyme contained with amylase, protease, mannanase, and xylanase. 
Table 6. Effects of dietary supplementation of exogenous multi-enzyme containing phytase on intestinal morphology in broilers

\begin{tabular}{|c|c|c|c|c|c|c|c|c|}
\hline \multirow{2}{*}{ Items } & \multicolumn{2}{|c|}{-Enzyme } & \multicolumn{2}{|c|}{ +Enzyme ${ }^{1)}$} & \multirow{2}{*}{ SEM } & \multicolumn{3}{|c|}{ p-value } \\
\hline & -Phytase & +Phytase & -Phytase & +Phytase & & $E$ & $\mathbf{P}$ & ExP \\
\hline \multicolumn{9}{|l|}{ Duodenum } \\
\hline $\mathrm{CD}(\mu \mathrm{m})$ & $160.95^{\mathrm{a}}$ & $155.71^{\mathrm{ab}}$ & $139.84^{\mathrm{ab}}$ & $132.67^{b}$ & 8.76 & 0.018 & 0.485 & 0.913 \\
\hline $\mathrm{VH} / \mathrm{CD}$ & $10.79^{b}$ & $11.18^{\mathrm{ab}}$ & $12.73^{\mathrm{ab}}$ & $13.57^{\mathrm{a}}$ & 0.83 & 0.015 & 0.466 & 0.791 \\
\hline \multicolumn{9}{|l|}{ Jejunum } \\
\hline $\mathrm{VH} / \mathrm{CD}$ & $7.67^{b}$ & $8.85^{\mathrm{ab}}$ & $9.78^{\mathrm{ab}}$ & $11.65^{\mathrm{a}}$ & 1.14 & 0.043 & 0.201 & 0.772 \\
\hline \multicolumn{9}{|l|}{ Ileum } \\
\hline $\mathrm{VH}(\mu \mathrm{m})$ & $702.91^{b}$ & $714.83^{b}$ & $731.90^{\mathrm{ab}}$ & $753.04^{\mathrm{a}}$ & 12.62 & 0.013 & 0.203 & 0.719 \\
\hline $\mathrm{CD}(\mu \mathrm{m})$ & $115.90^{\mathrm{a}}$ & $102.97^{\mathrm{ab}}$ & $93.73^{\mathrm{ab}}$ & $90.26^{b}$ & 7.92 & 0.043 & 0.327 & 0.570 \\
\hline $\mathrm{VH} / \mathrm{CD}$ & $6.34^{\mathrm{b}}$ & $7.16^{\mathrm{ab}}$ & $8.95^{\mathrm{a}}$ & $8.67^{\mathrm{ab}}$ & 0.81 & 0.026 & 0.756 & 0.535 \\
\hline
\end{tabular}

SEM, standard error of means; E, multienzyme; P, phytase; $V H$, villus height; $C D$, crypt depth.

1) Enzyme, multi-exogenous enzyme contained with amylase, protease, mannanase, and xylanase.

a,b Means within a row with unlike superscripts differ significantly $(p<0.05)$.

provement of villus height and crypt depth ratio (VH:CD) comparing to basal diets or dietary supplemental phytase treatment group $(\mathrm{p}<0.05)$.

\section{DISCUSSION}

In this study, dietary supplementation of phytase and multienzyme in combination improved the BWG and feed efficiency in broilers fed corn-wheat-SBM based diets. The supplementation of exogenous enzymes can improve nutrient utilization in the cereal grains by decreasing the intestinal viscosity in broilers [21]. The growth performance was in agreement with results reported by Singh et al [22], who observed that supplementation of the combined enzymes such as xylanase, amylase, protease, and phytase increased the BWG by about $10 \%$ to $15 \%$ and decreased FCR by 0.06 to 0.11 units in broilers fed corn-SBM diet or corn-wheatSBM based diet. However, Yaghobfar and Kalantar [23] reported that supplementation of glycanase and phytase in combination in corn-wheat based diet did not affect the weight gain and feed conversion rate of broilers. The different effects of carbohydrase and phytase on growth performance of broilers would be due to feed ingredients and enzyme type [24]. Wheat is rich source of arabinoxylans that consists of a backbone of $\beta$ - $(1,4)$-linked xylose residues, which are substituted with arabinose residues on the $\mathrm{C}(\mathrm{O})-2$ and/or $\mathrm{C}(\mathrm{O})-3$ position [25]. The supplemental xylanase and phytase are required in poultry diets based on wheat. Xylanase degrades arabinoxylans in the cell wall, releasing encapsulated starch and other nutrients from inside the cell wall, at the same time as reducing digesta viscosity caused by the soluble fraction [26]. Furthermore, phytase hydrolyze phosphate from phytic acid in a sequential process, resulting a myo-inositol and phosphate with the liberated nutrients, which were linked to phytic acid $[27,28]$. The combination of glycosidase and phytase can increase the accessibility to phytate more than being used individually [21]. That phytate molecules in wheat encased proteins in the aleuron layer by complex carbohydrates [29]. In this study, exogenous multi-enzyme and phytase synergistically improved not only ATTD but also AID in DM, GE, CP, Ca, and P. The improvement in nutrients digestibility may be associated with dietary enzymes including amylase, protease, $\beta$-mannanase, and xylanase, and phytase to degrade dietary NSP. In agreement, Lu et al [24] obtained that the use of xylanase, $\beta$-glucanase, and phytase in combination improved the DM, GE, CP, and P in chickens fed the ME (Please write it in full form.), $\mathrm{CP}, \mathrm{Ca}$, and $\mathrm{P}$ deficient diet during the growth phase. Furthermore, the improved protein digestibility was obtained when xylanase and $\beta$-glucanase were supplied in wheat-based diets [30]. However, Cowieson and Adeola [31] showed no interactive effects of xylanase, amylase, protease and phytase on nutrients digestibility and ileal digestible energy. Dietary supplemental $\beta$-mannanase that hydrolyzes $\beta$-mannan to the 1,4- $\beta$-D mannan chain of glucomannans and galactomannans can ameliorate energy and nutrient utilization in SBM as containing $\beta$-mannan, $\beta$-glucomannan, and $\beta$-galactomannan $[32,33]$. Li et al [34] reported that supplementation of $\beta$-mannanase improved the apparent metabolizable energy and protein digestibility of broilers. In addition, it was reported that the multi-enzyme containing xylanase, amylase, protease, and phytase in ME and $\mathrm{P}$ deficient diets showed a synergistic increase on growth performance and ileal phosphorus digestibility [35]. The Ca and $\mathrm{P}$ concentration in serum were increased with supplementation of exogenous multi-enzyme and phytase in 
combination with an increase of digestibility on this study. A similar result was observed by $\mathrm{Lu}$ et al [24] who reported that the addition of xylanase, $\beta$-glucanase, and phytase in combination in deficient diets increased the $\mathrm{P}$ concentration in serum of broiler chickens.

The gastrointestinal microbiota is one of the most factors determining immunity and physiological systems of broiler chickens. Pathogenic bacteria such as coliforms enhance infections and decrease the growth performance of chickens $[36,37]$. In this study, the supplementation of multi-enzyme showed a tendency for increasing Lactobacillus population and decreasing the colonization of E. coli and Clostridiums spp. in the ileum and cecum. The effect of exogenous enzyme such as $\beta$-mannanase and xylanase on intestinal microorganism have been observed in previous studies [36-39]. Roofchaei et al [40] detected that the dietary supplemental xylanase, $\beta$-glucanase, and phytase in combination had an inhibitory effect on the E. coli population in the ileum. It is well described that the oligosaccharides caused from action of xylanase or $\beta$-mannanase may alter the microbial population in the intestinal tract of broilers $[41,42]$. Xylanase degrades arabinoxylan, a major NSP found in wheat, producing shorter chain xylo-oligomers that are involved in production of short chain fatty acid (SCFA) in hindgut of broilers [43]. The produced SCFA may instigate environmental conditions favorable for lactic acid bacteria such as Lactobacillus spp. [44], which impedes pathogenic microbial propagation [45]. Furthermore, Yaghobfar and Kalantar [23] reported that the decrease of $E$. coli population and increase of Lactobacillus population in the ileum were observed by supplementation of $\beta$-glucanase and phytase. Phytase can alter the digesta $\mathrm{pH}$ and the ileal microbial population by reducing the buffering capacity of a $\operatorname{diet}[46,47]$.

In the present study, the broilers fed a diet supplemented with the combination of multi-enzyme and phytase improved villus height and crypt depth in duodenum, jejunum, and ileum. Dietary $\beta$-mannan (derived from SBM) and arabinoxylans (derived from wheat) cause an increase of digesta viscosity, which provokes change in the intestinal mucosa by accessing the mucosal surface to the viscous ingredients $[42,48]$. The digesta viscosity leads to quick changes in the intestinal mucosa due to the proximity of the mucosal surface to the intestinal viscose materials [23]. Therefore, grains such as wheat and SBM may induce shorter $\mathrm{VH}$ or deeper $\mathrm{CD}$ by stimulating division and tissue renewal of intestinal cells [49]. The supplementation of xylanase and $\beta$-mannanase in corn-wheat-SBM based diets might have alleviated the increase of digesta viscosity of broilers in this study. In a study [50], dietary supplemental xylanase decreased the digesta viscosity of in the jejunum of broilers. Furthermore, the effect on the small intestinal morphology might be due to butyrate production in hindgut. The supplementation of xylanase and $\beta$-mannanase in diet containing wheat and SBM lead to release xylo-oligosaccharides and manno-oligosaccharides, respectively in gut of broilers $[42,45,51]$, producing butyrate that plays a role as stimulator of glucagon-like peptide 2 (GLP-2) production. This hormone is secreted by entero-endocrine L cells localized in stomach, small intestine, colon and subepithelial myofibroblasts and acts as multiple downstream mediators [52]. Hu et al [53] reported that GLP-2 injection increased the small intestinal weight and the villus height of duodenum and jejunum of broiler chickens. The results in this study are in accordance with the observations of Roofchaei et al [40] who reported that dietary supplemental xylanase, $\beta$-glucanase, and phytase in combination increased villus length compared to control diet without supplemental enzyme.

In conclusion, the addition of phytase and multi-enzyme in broiler diet consisted of corn, wheat, and SBM showed synergistical improvement on growth performance and utilization of nutrients. Furthermore, the increased intestinal villus would be more likely from synergistical effect of supplementation with multi-enzyme containing xylanase and $\beta$-mannanase, and phytase. Our study suggests that supplemental xylanase, $\beta$-mannannase, and phytase in corn-wheatSBM based diets may derive advantages in broiler chickens.

\section{CONFLICT OF INTEREST}

We certify that there is no conflict of interest with any financial organization regarding the material discussed in the manuscript. Ingale SL is an employee of Advanced Enzyme Technologies Ltd..

\section{ACKNOWLEDGMENTS}

The research funding was provided by Advanced Enzyme Technologies Ltd., Thane, 400604, India.

\section{REFERENCES}

1. Amerah A. Interactions between wheat characteristics and feed enzyme supplementation in broiler diets. Anim Feed Sci Technol 2015;199:1-9. https://doi.org/10.1016/j.anifeedsci. 2014.09.012

2. Choct M. Feed non-starch polysaccharides: chemical structures and nutritional significance. Feed Milling Int 1997;191: 13-26.

3. Malathi V, Devegowda G. In vitro evaluation of nonstarch polysaccharide digestibility of feed ingredients by enzymes. Poult Sci 2001;80:302-5. https://doi.org/10.1093/ps/80.3.302

4. Jamroz D, Jakobsen K, Knudsen KEB, Wiliczkiewicz A, Orda J. Digestibility and energy value of non-starch polysaccharides in young chickens, ducks and geese, fed diets containing high 
amounts of barley. Comp Biochem Physiol A Mol Integr Physiol 2002;131:657-68. https://doi.org/10.1016/S10956433(01)00517-7

5. Choct M, Annison G. Anti-nutritive effect of wheat pentosans in broiler chickens: Roles of viscosity and gut microflora. Br Poult Sci 1992;33:821-34. https://doi.org/10.1080/000716 69208417524

6. Choct M, Annison G. The inhibition of nutrient digestion by wheat pentosans. Br J Nutr 1992;67:123-32. https://doi. org/10.1079/BJN19920014

7. Hetland H, Choct M, Svihus B. Role of insoluble non-starch polysaccharides in poultry nutrition. Worlds Poult Sci J 2004; 60:415-22. https://doi.org/10.1079/WPS200325

8. Meng X, Slominski BA. Nutritive values of corn, soybean meal, canola meal, and peas for broiler chickens as affected by a multicarbohydrase preparation of cell wall degrading enzymes. Poult Sci 2005;84:1242-51. https://doi.org/10.1093/ ps/84.8.1242

9. Dessimoni GV, Sakomura NK, Donato DCZ, Goldflus F, Ferreira NT, Dalólio FS. Effect of supplementation with Escherichia coli phytase for broilers on performance, nutrient digestibility, minerals in the tibia and diet cost. Semin Ciênc Agrár 2019;40:767-80. https://doi.org/10.5433/1679-0359. 2019v40n2p767

10. Ravindran, V. Feed enzymes: The science, practice, and metabolic realities. J Appl Poult Res 2013;22:628-36. https://doi. org/10.3382/japr.2013-00739

11. Katukurunda KGSC, Atapattu NSBM, Perera PWA. Effects of mega doses of phytase on growth performance, bone status and nutrient excretion of broilers fed diets containing high levels of rice bran. Iran J Appl Anim Sci 2017;7:119-27.

12. Olukosi OA, González-Ortiz G, Whitfield H, Bedford MR. Comparative aspects of phytase and xylanase effects on performance, mineral digestibility, and ileal phytate degradation in broilers and turkeys. Poult Sci 2020;99:1528-39. https:// doi.org/10.1016/j.psj.2019.11.018

13. Amerah AM, Romero LF, Awati A, Ravindran V. Effect of exogenous xylanase, amylase, and protease as single or combined activities on nutrient digestibility and growth performance of broilers fed corn/soy diets. Poult Sci 2017;96:80716. https://doi.org/10.3382/ps/pew297

14. Hashemi M, Seidavi A, Javandel F, Gamboa S. Influence of non-starch polysaccharide-degrading enzymes on growth performance, blood parameters, and carcass quality of broilers fed corn or wheat/barley-based diets. Rev Colom Cienc Pecu 2017;30:286-98. http://doi.org/10.17533/udea.rccp.v30n4a04

15.Liu WC, Kim IH. Effects of dietary xylanase supplementation on performance and functional digestive parameters in broilers fed wheat-based diets. Poult Sci 2017;96:566-73. https://doi.org/10.3382/ps/pew258

16. Wu YB, Ravindran V, Thomas DG, Birtles MJ, Hendriks WH. Influence of phytase and xylanase, individually or in combination, on performance, apparent metabolisable energy, digestive tract measurements and gut morphology in broilers fed wheat-based diets containing adequate level of phosphorus. Br Poult Sci 2004;45:76-84. https://doi.org/10.1080/0007166 0410001668897

17.Committee on Nutrient Requirements of Poultry, National Research Council. Nutrient requirements of poultry. 9th ed. Washington, DC, USA: National Academy Press; 1994.

18. AOAC. Official methods of analysis, Association of Official Analytical Chemists 18th Edition. Washington DC, USA: AOAC International; 2007.

19. Fenton TW, Fenton M. An improved procedure for the determination of chromic oxide in feed and feces. Can J Anim Sci 1979;59:631-4. https://doi.org/10.4141/cjas79-081

20. Kim JS, Ingale SL, Kim YW, et al. Effect of supplementation of multi-microbe probiotic product on growth performance, apparent digestibility, cecal microbiota and small intestinal morphology of broilers. J Anim Physiol Anim Nutr 2012; 96:618-26. https://doi.org/10.1111/j.1439-0396.2011.01187.x

21.Juanpere J, Perez-Vendrell A, Angulo E, Brufau J. Assessment of potential interactions between phytase and glycosidase enzyme supplementation on nutrient digestibility in broilers. Poult Sci 2005;84:571-80. https://doi.org/10.1093/ps/84.4. 571

22.Singh AS, Berrocoso JF, Dersjant-Li Y, Awati A, Jha R. Effect of a combination of xylanase, amylase and protease on growth performance of broilers fed low and high fiber diets. Anim Feed Sci Technol 2017;232:16-20. https://doi.org/10.1016/ j.anifeedsci.2017.07.012

23. Yaghobfar A, Kalantar M. Effect of non-starch polysaccharide (nsp) of wheat and barley supplemented with exogenous enzyme blend on growth performance, gut microbial, pancreatic enzyme activities, expression of glucose transporter (sglt1) and mucin producer (muc2) genes of broiler chickens. Braz J Poult Sci 2017;19:629-38. https://doi.org/10.1590/18069061-2016-0441

24.Lu H, Adedokun SA, Preynat A, et al. Impact of exogenous carbohydrases and phytase on growth performance and nutrient digestibility in broilers. Can J Anim Sci 2013;93: 243-9. https://doi.org/10.4141/cjas2012-138

25.Sharma P, Bhandari C, Kumar S, Sharma B, Bhadwal P, Agnihotri N. Dietary fibers: a way to a healthy microbiome. In: Holban AM, Grumezescu AM, editors. Diet, microbiome and health. London, UK: Academic Press; 2018. p. 299-345. https://doi.org/10.1016/B978-0-12-811440-7.00011-9

26. Amerah AM. Interactions between wheat characteristics and feed enzyme supplementation in broiler diets. Anim Feed Sci Technol 2015;199:1-9. https://doi.org/10.1016/j.anifeedsci. 2014.09.012

27.Wyss M, Brugger R, Kronenberger A, et al. Biochemical characterization of fungal phytases (myo-inositol hexakisphosphate phosphohydrolases): catalytic properties. Appl 
Environ Microbiol 1999;65:367-73. https://doi.org/10.1128/ AEM.65.2.367-373.1999

28. Yu S, Cowieson A, Gilbert C, Plumstead P, Dalsgaard S. Interactions of phytate and myo-inositol phosphate esters $\left(\mathrm{IP}_{1-5}\right)$ including $\mathrm{IP}_{5}$ isomers with dietary protein and iron and inhibition of pepsin. J Anim Sci 2012;90:1824-32. https:// doi.org/10.2527/jas.2011-3866

29. Heard PJ, Feeney KA, Allen GC, Shewry PR. Determination of the elemental composition of mature wheat grain using a modified secondary ion mass spectrometer (SIMS). Plant J 2002;30:237-45. https://doi.org/10.1046/j.1365-313X.2001. 01276.x

30. Wang ZR, Qiao SY, Lu WQ, Li DF. Effects of enzyme supplementation on performance, nutrient digestibility, gastrointestinal morphology, and volatile fatty acid profiles in the hindgut of broilers fed wheat-based diets. Poult Sci 2005;84: 875-81. https://doi.org/10.1093/ps/84.6.875

31. Cowieson AJ, Adeola O. Carbohydrases, protease, and phytase have an additive beneficial effect in nutritionally marginal diets for broiler chicks. Poult Sci 2005;84:1860-7. https://doi. org/10.1093/ps/84.12.1860

32. McCleary BV. Enzymatic modification of plant polysaccharides. Int J Biol Macromol 1986;8:349-54. https://doi.org/ 10.1016/0141-8130(86)90054-1

33.Zou XT, Qiao XJ, Xu ZR. Effect of $\beta$-mannanase (Hemicell) on growth performance and immunity of broilers. Poult Sci 2006;85:2176-9. https://doi.org/10.1093/ps/85.12.2176

34.Li Y, Chen X, Chen Y, Li Z, Cao Y. Effects of $\beta$-mannanase expressed by Pichia pastoris in corn-soybean meal diets on broiler performance, nutrient digestibility, energy utilization and immunoglobulin levels. Anim Feed Sci Technol 2010; 159:59-67. https://doi.org/10.1016/j.anifeedsci.2010.05.001

35. Olukosi OA, Cowieson AJ, Adeola O. Age-related influence of a cocktail of xylanase, amylase, and protease or phytase individually or in combination in broilers. Poult Sci 2007; 86:77-86. https://doi.org/10.1093/ps/86.1.77

36.Lei XJ, Lee KY, Kim IH. Performance, egg quality, nutrient digestibility, and excreta microbiota shedding in laying hens fed corn-soybean-meal-wheat-based diets supplemented with xylanase. Poult Sci 2018;97:2071-7. https://doi.org/10.3382/ ps/pey041

37.Lan R, Li T, Kim IH. Effects of xylanase supplementation on growth performance, nutrient digestibility, blood parameters, fecal microbiota, fecal score and fecal noxious gas emission of weaning pigs fed corn-soybean meal-based diet. Anim Sci J 2017;88:1398-405. https://doi.org/10.1111/asj.12771

38. Upadhaya SD, Park JW, Lee JH, Kim IH. Efficacy of $\beta$-mannanase supplementation to corn-soya bean meal-based diets on growth performance, nutrient digestibility, blood urea nitrogen, faecal coliform and lactic acid bacteria and faecal noxious gas emission in growing pigs. Arch Anim Nutr 2016;70:33-43. https://doi.org/10.1080/1745039X.2015.

\section{7}

39.Zheng L, Cho SH, Kang CW, Lee KW, Kim KE, An BK. Effects of $\beta$-mannanase on egg production performance, egg quality, intestinal microbiota, viscosity, and ammonia concentration in laying hens. Braz J Poult Sci 2020;22:1-8. https://doi.org/ 10.1590/1806-9061-2019-1180

40. Roofchaei A, Rezaeipour V, Vatandour S, Zaefarian F. Influence of dietary carbohydrases, individually or in combination with phytase or an acidifier, on performance, gut morphology and microbial population in broiler chickens fed a wheatbased diet. Anim Nutr 2019;5:63-7. https://doi.org/10.1016/ j.aninu.2017.12.001

41.Bedford MR, Cowieson AJ. Exogenous enzymes and their effects on intestinal microbiology. Anim Feed Sci Technol 2012;173:76-85. https://doi.org/10.1016/j.anifeedsci.2011. 12.018

42. Shastak Y, Ader P, Feuerstein D, Ruehle R, Matuschek M. $\beta$-Mannan and mannanase in poultry nutrition. Worlds Poult Sci J 2015;71:161-74. https://doi.org/10.1017/S00439 33915000136

43. Courtin CM, Swennen K, Broekaert WF, et al. Effects of dietary inclusion of xylooligo- saccharides, arabinoxylooligosaccharides and soluble arabinoxylan on the microbial composition of caecal contents of chickens. J Sci Food Agric 2008;88: 2517-22. https://doi.org/10.1002/jsfa.3373

44.Lee SA, Apajalahti J, Vienola K, González-Ortiz G, Fontes CMGA, Bedford MR. Age and dietary xylanase supplementation affects ileal sugar residues and short chain fatty acid concentration in the ileum and caecum of broiler chickens. Anim Feed Sci Technol 2017;234:29-42. https://doi.org/10. 1016/j.anifeedsci.2017.07.017

45.Craig AD, Khattak F, Hastie P, Bedford MR, Olukosi OA. Xylanase and xylo- oligosaccharide prebiotic improve the growth performance and concentration of potentially prebiotic oligosaccharides in the ileum of broiler chickens. Br Poult Sci 2020;61:70-8. https://doi.org/10.1080/00071668.2019. 1673318

46.Ptak A, Bedford MR, Świątkiewicz S, Żyła K, Józefiak D. Phytase modulates ileal microbiota and enhances growth performance of the broiler chickens. PloS One 2015;10:e0119 770. https://doi.org/10.1371/journal.pone.0119770

47.Sharma NK, Choct M, Wu SB, et al. Performance, litter quality and gaseous odour emissions of broilers fed phytase supplemented diets. Anim Nutr 2016;2:288-95. https://doi.org/10. 1016/j.aninu.2016.10.003

48. Saki AA, Matin HRH, Tabatabai MM, Zamani P, Harsini RN. Microflora population, intestinal condition and performance of broilers in response to various rates of pectin and cellulose in the diet. Eur Poult Sci 2010;74:183-8.

49. Iji PA, Saki AA, Tivey DR. Intestinal development and body growth of broiler chicks on diets supplemented with nonstarch polysaccharides. Anim Feed Sci Technol 2001;89:175- 
88. https://doi.org/10.1016/S0377-8401(00)00223-6

50.Lei Z, Shao Y, Yin X, Yin D, Guo Y, Yuan J. Combination of xylanase and debranching enzymes specific to wheat arabinoxylan improve the growth performance and gut health of broilers. J Agric Food Chem 2016;64:4932-42. https://doi. org/10.1021/acs.jafc.6b01272

51. Ravn JL, Thøgersen JC, Eklöf J, et al. GH11 xylanase increases prebiotic oligosaccharides from wheat bran favouring butyrateproducing bacteria in vitro. Anim Feed Sci Technol 2017;226: 113-23. https://doi.org/10.1016/j.anifeedsci.2017.02.011
52. De Maesschalck C, Eeckhaut V, Maertens L, et al. Effects of xylo-oligosaccharides on broiler chicken performance and microbiota. Appl Environ Microbiol 2015;81:5880-8. https:// doi.org/10.1128/AEM.01616-15

53. Hu XF, Guo YM, Huang BY, et al. The effect of glucagon-like peptide 2 injection on performance, small intestinal morphology, and nutrient transporter expression of stressed broiler chickens. Poult Sci 2010;89:1967-74. https://doi.org/10.3382/ ps.2009-00547 